TITLE:

\title{
Function of meiobenthos and microorganisms in cellulose breakdown in sediments of wetlands with different origins in Hokkaido
}

\section{AUTHOR(S):}

Yamada, Kyohei; Toyohara, Haruhiko

\section{CITATION:}

Yamada, Kyohei ...[et al]. Function of meiobenthos and microorganisms in cellulose breakdown in sediments of wetlands with different origins in Hokkaido. Fisheries Science 2012, 78(3): 699-706

\section{ISSUE DATE:}

2012-05

URL:

http://hdl.handle.net/2433/156154

\section{RIGHT:}

The final publication is available at www.springerlink.com; この論文は 出版社版でありません。引用の際には出版社版をご確認ご利用くださ $\iota_{\circ}$; This is not the published version. Please cite only the published version. 
1 Function of meiobenthos and microorganisms in cellulose breakdown in sediments

2 of wetlands with different origins in Hokkaido

3

4

5 Kyohei Yamada $\cdot$ Haruhiko Toyohara

6 Division of Applied Biosciences, Graduate School of Agriculture, Kyoto University,

$7 \quad$ Kyoto 606-8502, Japan

8

9 Corresponding author

10 Haruhiko Toyohara

11 Tel/Fax: 81-075-753-6446

12 Email: toyohara@kais.kyoto-u.ac.jp 
14 Abstract

15 To validate the mechanism of cellulose breakdown in cold climate wetlands, we

16 investigated cellulase activity in sediments collected from 17 wetland sites in Hokkaido,

17 the northern area of Japan. We evaluated cellulase activity by quantitative analysis of

18 glucose released from carboxymethyl cellulose and found that sediments from peat fens

19 demonstrated high activity, followed by sediments from lagoons and estuaries.

20 Sediments from peat fens also contained greater amounts of organic matter, followed by

21 lagoons and estuaries, thereby suggesting a strong positive correlation between organic

22 matter content and cellulase activity. Evaluation of cellulase activity by qualitative

23 cellulose zymographic analysis showed that various cellulases with different molecular

24 sizes were implicated in cellulose breakdown in wetlands. Among them, cellulose

25 breakdown in Meguma Pond (peat fen), Notsuke Gulf (peat fen) and Lake Utonai

26 (lagoon) was potentially due to microorganism cellulase, while that in Lake Chobushi

27 (lagoon) was ascribed to meiobenthos (Oligochaeta species) cellulase. The findings

28 presented herein suggest that the origin and activity level of cellulase varied, depending

29 on the types of cold climate wetlands.

30 Keywords: Cellulase $\cdot$ Cellulose $\cdot$ Cold district $\cdot$ Microorganism $\cdot$ Hokkaido

Meiobenthos $\cdot$ Sediment $\cdot$ Wetland 
33

34

35

36

37

38

39

40

41

42

\section{Introduction}

34

35

Wetlands play ecologically important roles as breeding grounds and stopping

points for migratory birds, as well as habitats for aquatic invertebrates, because of the

richness of nutrients derived from rivers, lakes, and seas [1]. Cellulose, a component of

plant cell walls, is a major organic material in the sediment of wetlands. Cellulose is a

high-molecular-weight polysaccharide comprised of $\beta$-1,4-linked glucose residues and biochemically stable compared to starch, in which glucose residues are bound by $\alpha-1,4$

linkages and $\alpha-1,6$ linkages [2,3]. Cellulase, which is a general term for enzymes that

belong to the glycoside hydrolase family and catalyzes the hydrolysis of the

$\beta$-1,4-glycoside linkages of cellulose chains, includes endo- $\beta$-1,4-glucanase (EC

3.2.1.4) and cellobiohydrolase (EC 3.2.1.91). Endo- $\beta$-1,4-glucanase and

cellobiohydrolase degrade cellulose to cellulodextrin or cellobiose, and another enzyme

$\beta$-glucosidase (EC 3.2.1.21) further degrades them into glucose [4]. Cellulases from

bacteria [5], filamentous fungi [6], basidiomycetes [7], myxomycetes [8], and protozoa

[9] have been extensively studied. Occurrence of cellulase of which genes are encoded

on chromosomes of their own have been reported from termite [10] and nematoda [11,

12]. Occurrence of these endogenous cellulases has also been reported in aquatic 
51 animals, such as blue mussels, abalones, sea urchins [13, 14, 15], and brackish clam

$52 \quad[16]$.

Cellulase and $\beta$-acetylglucosaminidase activities in sediments collected from

54 various wetlands in Japan were measured as part of the research conducted for The

55 International Collaborative Research on the Management of Wetland Ecosystem of the

56 National Institute for Environmental Studies between 1998 and 2002 [17]. In this report,

57 high cellulase activities were detected in the sediments from Lake Furen and Biwase

58 River, located in the east area of Hokkaido Prefecture of Japan, and the activities were

59 assumed to be derived from microorganisms. Recently, it was shown that the cellulase

60 activities in these northern areas of Japan can be ascribed to meiobenthos, but not to

61 microorganisms, and suggested that meiobenthos play an important role in the

62 breakdown of cellulose, especially in cold climates [18]. Meiobenthos are defined as animal that pass through a 1-mm mesh filter and are known to be composed of a variety of fauna corresponding to 22 phyla [19]. number of wetlands on the registry of the 500 most important wetlands in Japan maintained by the Ministry of Environment [20] and Ramsar Convention [21]. Wetlands are classified as lakes, rivers, or estuaries. Hokkaido has many lakes, most of which are 
69 classified as lagoons that were formed when a part of the sea was enclosed by land.

70 Many lagoons are located in Hokkaido (e.g., Lake Saroma and Lake Furen).

71 Land-derived organic matter accumulates more easily in lagoons than in estuaries,

72 because lagoons have only a narrow mouth open to the sea [22]. Many peat fens are

73 localized in the eastern and northern parts of Hokkaido, because cellulose breakdown by

74 microorganisms is suppressed at low level due to low temperature throughout a year.

75 For example, annual mean temperatures around Meguma Pond and Notsuke Gulf in

762010 were $6.7^{\circ} \mathrm{C}$ and $6.3^{\circ} \mathrm{C}$, respectively (Japan Meteorological Agency Web:

77 http://www.jma.go.jp/ “Accessed 19 August 2011”.). Because enough amount of

78 cellulose derived from undecayed plants in peat fens could be available, it is assumed

79 that various cellulose consumers inhabit there [23]. Although various types of wetlands

80 located in Hokkaido are presumed to be inhabited by diverse cellulose consumers such

81 as microorganisms and meiobenthos, it remains unknown what types of organisms are

82 mainly involved in cellulose breakdown in these wetlands.

84 wetlands, we compared the degree of cellulose breakdown among the different types of wetlands in Hokkaido and tried to identify major cellulose consumers in these wetlands. 
87

88

89

90

91

\section{Materials and methods}

Materials

Figure 1 shows the sampling sites and their latitude and longitude measured by

a handy GPS (eTrex Vista HCx; Garmin, Olathe, KS, USA). Sampling was performed from early to mid-August 2010 and from mid-September to early October 2010. We

collected sediments from 11 lagoons (Koetoi Onuma Pond, Lake Kuccharo, Lake

Saroma, Lake Notoro, Lake Abashiri, Lake Furen, Mochirippu Pond, Lake Akkeshi,

Pashikuru Pond, Lake Chobushi, and Lake Utonai), 2 peat fens (Notsuke Gulf and

Meguma Pond), and 4 estuaries (Teshio River, Ishikari River, Mukawa River, and Saru

River). Sediments from Lake Saroma, Lake Notoro, Lake Abashiri, Lake Akkeshi, Lake

Furen, Notsuke Gulf, Mochirippu Pond, Pashikuru Pond, and Lake Chobushi were

collected on August 9-12, 2010, and those from the other sites were collected from

September 29 to October 2, 2010. We collected approximately $1 \mathrm{~kg}$ of sediments from a depth of $5 \mathrm{~cm}$ of each collecting site. We selected one collecting site apparently without plants for each wetland and transported these samples at $4^{\circ} \mathrm{C}$ back to the laboratory at Kyoto University. Sediment samples were stored at $4^{\circ} \mathrm{C}$ until analyses. Salt 
105 concentration of environmental water from each sampling site was measured by a

106 salinometer (IS/Mill-E; AS ONE corporation, Osaka, Japan). Table 1 and Table 2 show

107 salinity and composition of grain sizes of each wetland, respectively. Unless otherwise

108 specified, special grades of reagents were commercially obtained from nacalai tesque

109 (Kyoto, Japan).

110

111 Measurement of sediment cellulase activity by quantitative analysis

Cellulase activity of sediments was measured within 2 weeks of collection,

114 according to the method of Hayano et al. [24], by using tetrazolium as a coloring agent

115 [25]. Five grams (wet weight) of sediment, passed through a $2 \mathrm{~mm}$-filter, was collected

116 in a $50 \mathrm{ml}$-conical tube and added to $0.5 \mathrm{ml}$ toluene for sterilization. Next, $10 \mathrm{ml}$ of 0.2

$117 \mathrm{M}$ acetate buffer (pH 5.9) and $10 \mathrm{ml}$ of $1 \%$ sodium carboxymethyl cellulose (CMC;

118 Sigma, St Louis, MO, US) were added and incubated in a water bath at $30^{\circ} \mathrm{C}$ for $24 \mathrm{~h}$

119 with shaking. The same reaction mixture containing water instead of CMC was used as

120 a control. After incubation, tubes were centrifuged at $8,000 \times g$ for $5 \mathrm{~min}$, and $100 \mu \mathrm{l}$ of

121 supernatant was added to a $1.5-\mathrm{ml}$ tube. One milliliter of blue tetrazolium was added to
Table 1

Table 2 
123 ASTEC, Fukuoka, Japan), and the absorbance at $660 \mathrm{~nm}$ was measured by a

124 spectrophotometer (UV mini 1240; Shimadzu Corporation, Kyoto, Japan) after cooling.

125 The value of the absorbance was converted to glucose concentration by using a standard

126 curve of glucose $(0-180 \mu \mathrm{g} / \mathrm{ml})$ created at the same time. The pellet obtained by

127 centrifugation was dried in a dryer (PS-420; ADVANTEC, Tokyo, Japan) at $60^{\circ} \mathrm{C}$

128 overnight to determine the dry weight. Cellulase activity was represented as the amount

129 of glucose released from CMC per $1 \mathrm{~g}$ sediment (dry weight) per $1 \mathrm{~h}$.

131 Isolation of meiobenthos

Meiobenthos were isolated alive from sediments within 1 week of collection.

134 Meiobenthos were recovered in the fraction that included materials small enough to pass

135 through a 1-mm mesh filter but too large to pass through a $63-\mu \mathrm{m}$ mesh filter. Each

136 meiobenthos was isolated under observation with a microscope (S2X12; Olympus,

137 Tokyo, Japan). Classification of meiobenthos was performed at the level of Class

138 according to Robert et al. [19] except for nematoda due to the difficulty in classification

139 of this species. Classification of arthropods was performed according to Joei et al. [26].

140 We used single body of meiobenthos for qualitative cellulase assay and two bodies for 
141 quantitative assay.

142 Cellulase activity of oligochaeta from Notsuke Gulf was measured

143 quantitatively according to the modified method of Niiyama and Toyohara [27]. Briefly,

144 two bodies of living oligochaeta were homogenized with cold $110 \mu \mathrm{l}$

145 phosphate-buffered saline (PBS, containing $140 \mathrm{mM} \mathrm{NaCl}, 2.7 \mathrm{mM} \mathrm{KCl}, 8 \mathrm{mM}$

$146 \mathrm{Na}_{2} \mathrm{HPO}_{4}$, and $1.5 \mathrm{mM} \mathrm{KH}{ }_{2} \mathrm{PO}_{4}, \mathrm{pH}$ 7.4). Then, $3 \mu \mathrm{l}$ of meiobenthos extract, $3 \mu \mathrm{l}$ of 1

147 M sodium acetate buffer ( $\mathrm{pH} 5.9$ ), and $24 \mu \mathrm{l}$ of $1 \% \mathrm{CMC}$ solution were mixed.

148 Reactions were carried out at $30^{\circ} \mathrm{C}$ and $4^{\circ} \mathrm{C}$ for $1,3,7,12$, and $24 \mathrm{~h}$ with shaking. After

149 incubation, the mixtures were heated at $100^{\circ} \mathrm{C}$ for $3 \mathrm{~min}$ in the block incubator

150 described above to terminate the enzyme reaction. The amount of reducing sugar

151 produced was measured by the tetrazolium blue method [25]. The absorbance at $660 \mathrm{~nm}$

152 was measured with a UV-mini 1240 spectrophotometer.

Preparation and culture of cellulose breakdown microorganisms

Sediment was spread on an agar plate $(1.5 \%$ agar containing $0.5 \% \mathrm{CMC}$,

$\left.0.15 \% \mathrm{Ca}\left(\mathrm{NO}_{3}\right)_{2}, 0.05 \% \mathrm{MgSO}_{4}, 0.05 \% \mathrm{~K}_{2} \mathrm{HPO}_{4}\right)$ and cultured at $25^{\circ} \mathrm{C}$ for 1 week.

Autoclaved $0.1 \%$ soft agar was then added to the cultured plate, and the surface of the 
159 plate containing microorganisms was scraped with a bacteria spreader. Soft agar

160 containing cultured microorganisms was added to a liquid culture medium ( $0.5 \% \mathrm{CMC}$,

$1610.15 \% \mathrm{Ca}\left(\mathrm{NO}_{3}\right)_{2}, 0.05 \% \mathrm{MgSO}_{4}$, and $\left.0.05 \% \mathrm{~K}_{2} \mathrm{HPO}_{4}\right)$ and cultured at $25^{\circ} \mathrm{C}$ for 1 week.

162 Culture medium was then filtered through paper filter (No. 1; Toyo Roshi Kaisha,

163 Tokyo, Japan), and the filtrate was used for SDS-PAGE zymographic analysis.

Measurement of cellulase activity by qualitative analysis with sodium dodecyl sulfate polyacrylamide gel electrophoresis (SDS-PAGE) zymography

An aliquot of sediment and a 1/5 volume of $6 \times$ SDS sample buffer (containing

$0.6 \mathrm{M}$ Tris- $\mathrm{HCl}$ (pH 6.8), 60\% glycerol, 6\% SDS, and 0.06\% bromophenol blue) were mixed with a homogenizer (HandySonic UR-20P; TOMY SEIKO, Tokyo, Japan), incubated on ice for $2 \mathrm{~h}$, and centrifuged at $8,000 \times g$ for $5 \mathrm{~min}$. The supernatant was used for SDS-PAGE zymographic analysis. Meiobenthos were picked up from the sediments one by one using a pair of tweezers under a binocular microscope (S2X12; Olympus, Tokyo, Japan), and each was then homogenized alive with cold $20 \mu \mathrm{PBS}$ to prepare a meiobenthos extract for 
177 follows. A nematoda obtained from Meguma Pond is 2-3 $\mathrm{mm}$ long and that from Lake

178 Utonai is $4 \mathrm{~mm}$ long. An oligochaeta species from Meguma Pond, Lake Notoro and

179 Lake Utonai is 1-2 mm long, $4 \mathrm{~mm}$ long, and $8 \mathrm{~mm}$ long, respectively. A polychaeta

180 species from Lake Utonai is 1-2 mm long. Maxillopoda species from Meguma Pond is 1

181 mm long.

Cellulase zymographic analysis was performed using 7.5\% SDS-PAGE gels

183 containing $0.1 \% \mathrm{CMC}$. After electrophoresis, the gels were soaked in $10 \mathrm{mM}$ acetate

184 buffer $(\mathrm{pH} 5.5)$ containing $0.1 \%$ TritonX-100 for $30 \mathrm{~min}$ to remove SDS from the gels.

185 The gels were transferred to $10 \mathrm{mM}$ acetate buffer ( $\mathrm{pH} 5.5)$, incubated at $37^{\circ} \mathrm{C}$ or $4^{\circ} \mathrm{C}$

186 overnight, and then stained with $0.1 \%$ Congo Red. In case of sediment of Notsuke Gulf,

187 the gel was incubated for 4 days because of low activity. The gels were destained using

$1881 \mathrm{M} \mathrm{NaCl}$. The active bands were detected as nonstained bands.

Measurement of organic component ratio

Dried sediment obtained as mentioned above was heated in a mantle heater 
195 was calculated according to the formula below.

196 Organic component ratio $(\%)=[($ dry weight - ignition weight $) /($ dry weight $)] \times 100$

$198 \quad$ Results

199

200 Comparison of cellulase activity level by quantitative cellulase analysis

201

Among 17 wetland sites in Hokkaido, Meguma Pond showed the highest

203 cellulase activity (peat fen, $737.88 \mathrm{nmol} / \mathrm{gh}$, Table 1), followed by Notsuke Gulf (peat

204 fen, $92.39 \mathrm{nmol} / \mathrm{gh}$ ), Lake Utonai (fresh water lagoon, $44.45 \mathrm{nmol} / \mathrm{gh}$ ), Lake Saroma

205 (lagoon, $28.48 \mathrm{nmol} / \mathrm{gh}$ ), Lake Akkeshi (lagoon, $21.42 \mathrm{nmol} / \mathrm{gh}$ ), and Lake Notoro

206 (lagoon, $13.86 \mathrm{nmol} / \mathrm{gh}$ ), as summarized in Table 1. Sediments from the estuaries of the

207 Teshio River, Ishikari River, Mukawa River, and Saru River showed little or no

208 cellulase activity.

209

210 Qualitative analysis of cellulases by SDS-PAGE zymography

Among 17 wetlands in Hokkaido, active cellulase bands were detected in all 
213 samples by SDS-PAGE zymographic analysis, except for sediments from Pashikuru

214 Pond, Mukawa River, Saru River, and Lake Abashiri (data not shown). For meiobenthos,

215 active cellulase bands were detected in the Oligochaeta species in Meguma Pond (Fig.

216 2), Notsuke Gulf (Fig. 2), Lake Notoro and Lake Abashiri (data not shown), Lake

217 Chobushi (Fig. 2), Lake Utonai (Fig. 2), Ishikari River, and Koetoi Onuma Pond (data

218 not shown); Malacostraca species in Lake Kuccharo (data not shown); Nematoda

219 species in Lake Saroma (data not shown); Foraminifera species in Lake Akkeshi (data not shown); and Polychaeta species in Teshio River (data not shown).

As shown in Fig. 2a, sediment from Meguma Pond demonstrated activity as a

broad smear above $38 \mathrm{kDa}$. For meiobenthos, Oligochaeta species showed an active

band at $48 \mathrm{kDa}$, but Nematoda species and Maxillopoda species showed no activity.

224 However, culture medium of microorganisms showed an active band of high molecular weight (above $199 \mathrm{kDa})$.

Figure $2 \mathrm{~b}$ shows the cellulase activity from the Notsuke Gulf sample. Sediment

exhibited intensive active bands at 33 and $87 \mathrm{kDa}$ and faint active bands at 49, 146, 172 and $244 \mathrm{kDa}$, while Oligochaeta species showed at 26, 29 and $30 \mathrm{kDa}$. On the other

$\mathrm{kDa}$. 
Figure 2c shows the cellulase activity from the Lake Notoro sample. Sediment

232 showed weak active bands at 24, 30, and $58 \mathrm{kDa}$. Oligochaeta species showed a strong

233 active band at $28 \mathrm{kDa}$ and a weak active band at $29 \mathrm{kDa}$. Ostracoda species

234 demonstrated a weak active band at $27 \mathrm{kDa}$, while the culture medium of

235 microorganisms showed active bands at 49, 108, and $230 \mathrm{kDa}$.

Figure $2 d$ shows results from the Lake Chobushi sample. Sediment showed

237 active bands at 33, 59, and $62 \mathrm{kDa}$, while Oligochaeta species showed active bands at

$30,33,36,38,43,59$, and $62 \mathrm{kDa}$. Although smear active bands were detected by 24

Oligochaeta species showed an active band at $68 \mathrm{kDa}$.

Demonstration of cellulase activity of meiobenthos at low temperature

As shown in Fig.3, Oligochaeta species demonstrated the substantial cellulase

247 activity bands at $4^{\circ} \mathrm{C}$ in zymographic analysis, of which activity levels were 
$249 \mathrm{kDa}$ active bands, while those in Lake Chobushi showed 36, 38, 43 and $59 \mathrm{kDa}$ active

250 bands.

Figure 4 shows the cellulase activity of oligochaeta species in Notsuke Gulf. 253 level at $4^{\circ} \mathrm{C}$ was almost corresponded with $30 \%$ of that at $30^{\circ} \mathrm{C}$.

255 Relationship between the amount of organic matter and cellulase activity level

As shown in Table 1, sediment from peat fens such as Meguma Pond and

258 Notsuke Gulf contained large amounts of organic matter, $66.6 \%$ and $16.9 \%$, respectively.

259 Sediments from lagoons such as Lake Saroma, Lake Akkeshi, and Lake Utonai

260 contained $1.5 \%, 6.4 \%$, and $1.5 \%$ organic matter, respectively. Sediments from the

261 estuaries of the Teshio River, Ishikari River, and Saru River contained 1.0\%, 0.1\%, and

$2620.1 \%$ organic matter, respectively. There was a strong positive correlation $(r=0.96)$

263 between the amount of organic matter and the cellulase activity level among sediments

264 collected from 17 wetlands. 
We measured cellulase activity in sediments collected from 17 wetlands in

269 Hokkaido to evaluate cellulose breakdown in cold climates. According to our

270 quantitative analysis (Table 1), sediments from peat fens showed the highest cellulase

271 activity, followed by those from lagoons and estuaries so far as measured on August

272 and September in the specific collecting site.

273

SDS-PAGE zymographic analysis revealed that the molecular size of active

274 cellulase bands in sediments from Notsuke Gulf (peat fen) corresponded with those

275 from culture medium of microorganisms. To confirm microorganism cellulases

276 actually act at cold temperature, we measured activity at $4^{\circ} \mathrm{C}$. As shown in Fig. 3(a),

277 culture medium of microorganisms showed active bands of 146 and $172 \mathrm{kDa}$,

278 suggesting that microorganism cellulases might play any function in cellulose

279 breakdown in Notsuke Gulf. The molecular sizes of active cellulase bands in the

280 sediments of Lake Chobushi (lagoon) corresponded with those from meiobenthos.

281 These findings suggest that microorganisms and meiobenthos play important roles in

282 cellulose breakdown, especially in these wetlands in Hokkaido. However, the

283 possibility that the molecular sizes of cellulase active bands of sediments and microorganisms/meiobenthos apparently coincided is not completely ruled out. Further 
285 immunological analysis is needed to validate that the active bands of sediments were

286 derived from microorganisms or meiobenthos.

$287 \quad$ Oligochaeta showed a strong active band that did not coincide with any bands

288 in the sediment samples from Lake Notoro (Fig. 2c). Despite the fact, it is assumed

289 that Oligochaeta species could play any function in cellulose breakdown in Hokkaido,

290 together with the fact that oligochaeta played an important role in Lake Chobushi as

291 described above. As shown in Fig.3, Oligochaeta species demonstrated the substantial

292 cellulase activity at $4^{\circ} \mathrm{C}$ in qualitative analysis. Oligochaeta species in Notsuke Gulf

293 actually demonstrated the activity at $4{ }^{\circ} \mathrm{C}$ almost corresponded with $30 \%$ of that at

$29430^{\circ} \mathrm{C}$ (Fig.4), suggesting that meiobenthos might play any role to degrade plant

295 residues at low temperature. Since same active bands were demonstrated at $4^{\circ} \mathrm{C}$ and

$29637^{\circ} \mathrm{C}$, these Oligochaeta species were assumed to possess cellulases active at broad

297 temperature range.

As shown in Table 1, a strong positive correlation was observed between the

299 amount of organic matter and the cellulase activity level. Based on the following facts;

300 (i) organic matters are assumed to be derived from plant residues [29], (ii) in Meguma

301 Pond and Notsuke Gulf where high content of organic matters are detected in sediments,

302 cellulase activity of sediments was derived from microorganisms (Figs. 2a and b), and 
303 (iii) microorganisms secrete cellulases extracellularly[30], (iv) Liu and Toyohara

304 reported that fungal cellulase actually bound to plant residues [31], it seems likely that

305 cellulases secreted from microorganisms would bind to plant residues and degrade them

306 in the wetlands of peat fen sediments. In our preliminary experiments, cellulases from

307 Corbicula japonica bound to plant residues similar to fungal cellulases (data not shown),

308 meiobenthos cellulases would function as sediment-binding form in sediment of

309 Hokkaido wetlands.

311 Acknowledgements

312 The authors sincerely thank Dr. Chihiro Tanaka, Graduate School of Agriculture, Kyoto

313 University for his help in culturing fungus. This study was partly supported by a

314 grant-in-aid for scientific research from the Ministry of Education, Culture, Sports,

315 Science, and Technology of Japan (no. 22255012).

316

\section{$317 \quad$ References}

1. Beukema JJ (1979) Biomass and species richness of the macrobenthic animals 


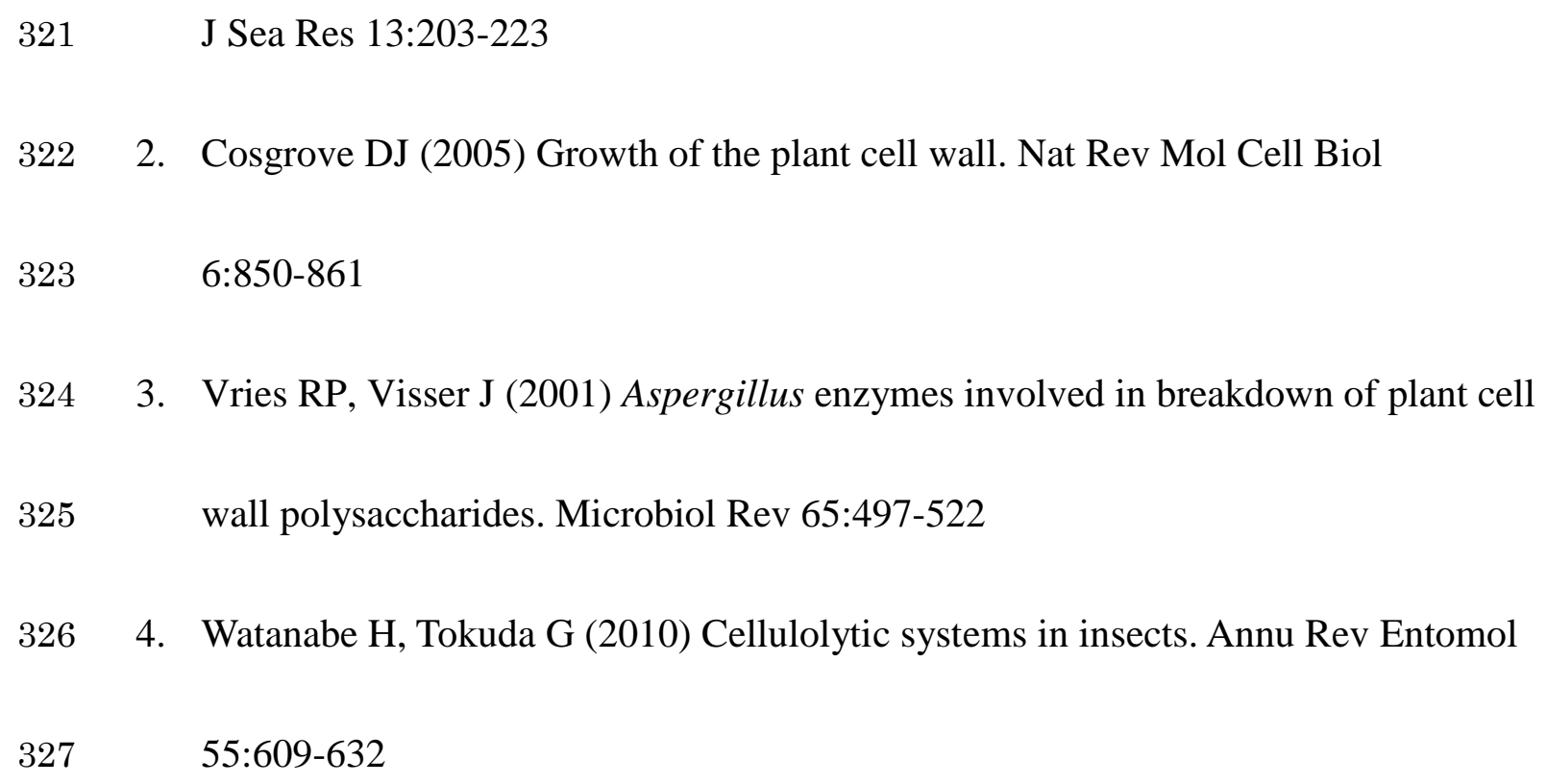
MK (1994) Anaerobic fungi in herbivorous animals. Mycol Res 98:129-152

7. Chow CM, Yague E, Raguz S, Wood DA, Thurston CF (1994) The cel3 gene of Agaricus-bisporus codes for a modular cellulase and is transcriptionally regulated by the carbon source. Appl Environ Microbiol 60:2779-2785

8. Ronsness PA (1968) Cellulolytic enzymes during morphogenesis in Dictyostelium discoideum. J Bacterial 96:639-645

9. Bera-Maillet C, Devillard E, Cezette M, Jouany JP, Forano E (2005) Xylanases and 
339 carboxymethylcellulases of the rumen protozoa Polyplastron multivesiculatum,

340 Eudiplodinium maggii and Entodinium sp. FEMS Microbiol Let 244:149-156

341 10. Watanabe H, Noda H, Tokuda G, Lo N (1998) A cellulase gene of termite origin.

$342 \quad$ Nature 394:330-331

343 11. Smant G, Stokkermans PWGJ, Yan Y, Boer de MJ, Baum JT, Wang XH, Hussey RS,

344 Gommers FJ, Henrissat B, Davis EL, Helder J, Schots A, Bakker J (1998)

345 Endogenous cellulases in animals: Isolation of $\beta-1,4$-endoglucanase genes from two

346 species of plant-parasitic cyst nematodes. Proc Natl Acad Sci USA 95:4905-4911

12. Kikuchi T, Shibuya H, Jones TJ (2005) Molecular and biochemical characterization

348 of an endo- $\beta-1,3$-glucanase from the pinewood nematode Bursaphelenchus

$349 x y l o p h i l u s$ acquired by horizontal gene transfer from bacteria. Biochem J $389: 117-125$

13. Xu BZ, Janson JC, Sellos D (2001) Cloning and sequencing of a molluscan endo-beta-1,4-glucanase gene from the blue mussel, Mytilus edulis. Eur J Biochem $268: 3718-3727$ from abalone Haliotis discus hannai. Eur J Biochem 270:771-778 
357 primary structure of a cellulase from the Japanese sea urchin Strongylocentrotus

$358 \quad$ nudus. Biochimie 89:1002-1011

359 16. Sakamoto K, Touhata K, Yamashita M, Kasai A, Toyohara H (2007) Cellulose

360 digestion by common Japanese freshwater clam Corbicula japonica. Fish Sci 73:675-683

17. National Institute for Environmental Studies, Japan (2003) International collaborative research on the management of wetland ecosystem (in Japanese). Report of special research from the National Institute for Environmental Studies, Japan, pp 8-13

18. Toyohara H, Park Y, Tsuchiya K, Liu W (2011) Cellulase activity in meiobenthos in wetlands. Fish Sci 78:133-137

19. Robert PH, Hjalmar T (1988) Introduction to the study of meiofauna. Smithsonian Institution Press, Washington, D.C, pp 243-354

20. Nature Convention Bureau in Japanese Ministry of the Environment (2002) Five hundred important wetlands in Japan (in Japanese). Nature Convention Bureau, Tokyo

21. Ramsar Convention Secretariat (2011) The list of wetlands of international importance. Ramsar Convention Secretariat, Ramsar, pp 21-22 
22. Wit R, Stal LJ, Lomstein BA, Herbert RA, van Gemerden H, Viaroli P, Cecherelli VU, Rodriguez-Valera F, Bartoli M, Giordani G, Azzoni R, Schaub B, Welsh DT, Donnelly A, Cifuentes A, Anton J, Finster K, Nielsen LB, Pedersen AGU, Neubauer AT, Colangelo MA, Heijs SK (2001) The role of buffering capacities in stabilising coastal lagoon ecosystems. Continent Shelf Res 21:2021-2041

23. Artz RRE, Anderson IC, Chapman SJ, Hagn A, Schloter M, Potts JM, Campbell CD (2007) Changes in fungal community composition in response to vegetational succession during the natural regeneration of cutover peatlands. Microbiol Ecol 54: $508-522$

24. Soil Microbiological Society (1992) Experimental methods for soil microbiology (in Japanese). Yokendo, Tokyo, pp 370-371

25. Chong K J, Peter N L (1985) Determination of reducing sugars in the nanomole range with tetrazolium blue. J Biochem Biophys Methods 11:109-115

26. Joei WM, Gorge ED (2001) An updated classification of the recent crustacean. Natural History Museum of Los Angeles Country, Los Angeles, pp 1-124

27. Niiyama T, Toyohara H (2011) Widespread distribution of cellulase and hemicellulase activities among aquatic invertebrates. Fish Sci 77: 649-655

28. Hwang I H, Ouchi Y, Matsuto T (2007) Characteristics of leachate from pyrolysis 
393 residue of sewage sludge. Chemosphere 68:1913-1919

394 29. Nguyen LM (2000) Organic matter composition, microbial biomass and microbial

395 activity in gravel-bed constructed wetlands treating farm dairy wastewaters. Ecol

$396 \quad$ Eng 16:199-221

397 30. Barnet CC, Berka RM, Fowler T (1991) Cloning and amplification of the gene

398 encoding an extracellular bold $\beta$-glucosidase from Trichoderma reesei: Evidence for

399 improved rates of saccharification of cellulosic substrates. Nat Biotechnol

$400 \quad 9: 562-567$

401 31. Liu W, Toyohara H (2012) Sediment-complex-binding cellulose breakdown in

402 wetlands of rivers. Fish Sci. Doi: 10.1007/s12562-012-0471-y 


\section{Figure captions}

405

406 Figure 1 Sampling sites of wetlands in Hokkaido. Geological types of wetlands are

407 classified into 3 types: lagoon, peat fen, or estuary. Letters indicating sampling sites

408 correspond to those in Table 1 and Table 2.

410 Figure 2 Qualitative analysis of cellulase activity by SDS-PAGE cellulose zymography

411 at $37^{\circ} \mathrm{C}$. (a) Meguma Pond: Lane 1, sediment; lane 2, Nematoda; lane 3, Oligochaeta;

412 lane 4, Maxillopoda; lane 5, microorganisms. (b) Notsuke Gulf: Lane 1, sediment; lane

413 2, Oligochaeta; lane 3, microorganisms. (c) Lake Notoro: Lane 1, sediment; lane 2,

414 Oligochaeta; lane 3, Ostracoda; lane 4, microorganisms. (d) Lake Chobushi: lane 1,

415 sediment; lane 2, Oligochaeta (24h-incubation); lane 3, Oligochaeta (10 h-incubation).

416 (e) Lake Utonai: Lane 1, sediment; lane 2, Nematoda; lane 3, Oligochaeta; lane 4,

417 microorganisms. Note that active bands of each animal do not reflect the enzyme

418 activity level correctly. Asterisks mean that the animal belongs to meiobenthos.

420 Figure 3 Qualitative analysis of cellulase activity of oligochaeta species from Notsuke

421 Gulf (a) and Lake Chobushi (b). (a) Notsuke Gulf: Lane 1, sediment; lane 2, 
1

2

3

4

5

6 7
422 Oligochaeta; lane 3, microorganism. Asterisks mean that the animal belongs to

423 meiobenthos.

424

425 Figure 4 Cellulase activity of oligochaeta species in Notsuke Gulf at $4{ }^{\circ} \mathrm{C}$ and $37^{\circ} \mathrm{C}$ as a

426 function of time. Values are mean \pm standard deviation $(n=3)$. 
森岡克司先生

前略

このたびはご審査賜りありがとうございました。1名の審査員のコメントに対し 下記のように対応いたしました。審査員の指示に従い追加実験を行ったため, 訂正原稿の提出が遅れたことをお詫びいたします。ご審査のほど，よろしくお 願いいたします。

草々

平成 24 年 2 月 19 日

京都大学農学研究科 豊原治彦

Major points

1. Fig. 2 について

1-1バンドパターンについて

前回から変更されたようですが、今一つ明暸なバンドが見えているようには感 じません。特にFig. 2b の sediment のレーンの 121 と 172kDa のバンドはどう見 ても（PC画面上でも印刷しても）はっきりとは見えません。この図ではとても 読者を納得させることはできませんので、sediment のレーン添加量を增やすか、 反応時間を長くすることにより明瞭なバンドを提示してください。Fig. 2elつ いてもゲル上部にスタックしているという意味では sediment と microorganism のセルラーゼは同じ性質をもつのかもしれませんが、これで両者を同じもので あると類推するのは無理があると感じます。上記二つのデータは / ine252-253 に記述されているように、本論文中で非常に重要な論拠となるデータですので、 Fig. 2b は再試を奨めます。Fig. 2e は再試で良い結果が出ないようであれば、 sediment の高分子量のバンドをmicroorganism に帰着させる記述を削除した方 が良いと思います。

一ご指摘に従い Fig. 2b の野付湾底泥については 4 日間の反応を行うことで、明 確な活性バンドを検出することができたので、そのデータと差し替えました。 訂正した部分は以下の通りです。

L186-187:In case of sediment of Notsuke Gulf, the gel was incubated for 4 days because of low activity. The gels were destained using $1 \mathrm{M} \mathrm{NaCl}$. The active bands were detected as nonstained bands. 
L226-230:Sediment exhibited intensive active bands at 33 and $87 \mathrm{kDa}$ and faint active bands at 49, 146, 172 and $244 \mathrm{kDa}$, while Oligochaeta species showed at 26, 29 and 30 $\mathrm{kDa}$. On the other hand, culture medium of microorganisms showed active bands at 108 , 146, 172 and $244 \mathrm{kDa}$.

一Fig. 2e については再試を行ってもバンドがスタックしてしまったため sediment の高分子バンドを microorganismに帰着させる記述を削除しました。 訂正した部分は以下の通りです

L273-275:SDS-PAGE zymographic analysis revealed that the molecular size of active cellulase bands in sediments from Notsuke Gulf (peat fen) corresponded with those from culture medium of microorganisms.

\section{1-2 分類に関して}

- Nematoda, Oligochaeta, Harpcitcoida, Ostracoda, Polychaetaはそれぞれ meiobenthos に属する種類であり、microorganismに比して解析していることは 図中に矢印、もしくは括弧等で示された方が分かりやすいと思います。

一ご指摘に従いそれぞれの生物が Meiobenthos であることが分かり易くなるよ うに図中に*で示しました。またそれに伴いFigure captionに記述を加えまし た。訂正した部分は以下の通りです。

L418: Asterisks mean that the animal belongs to meiobenthos

L422-423: Asterisks mean that the animal belongs to meiobenthos

・ またHarpcitcoida と Ostracoda は斜体になっています。一般に分類表記で斜 体は学名の属、種に使うもので、Harpcitcoida (ソコミジンコ目)、Ostracoda (カイムシ下綱) 等には使わないように感じます。もしなんらかの理由がある なら説明が必要かと思います。

—ご指摘の通り、表記を訂正しました。訂正した部分は以下の通りです。

L233:Ostracoda species demonstrated a weak active band at $27 \mathrm{kDa}$.

L414-415:(c) Lake Notoro: Lane 1, sediment; lane 2, Oligochaeta; lane 3, Ostracoda; lane 4 , microorganisms. 
L180:Maxillopoda species from Meguma Pond is $1 \mathrm{~mm}$ long.

L223:but Nematoda species and Maxillopoda species showed no activity.

L411-412:Meguma Pond: Lane 1, sediment; lane 2, Nematoda; lane 3, Oligochaeta; lane 4, Maxillopoda; lane 5, microorganisms.

・さらに、これは単なる suggestion ですが、上記の Nematoda（線形動物門）、 Oligochaeta (貟毛綱)、Polychaeta (多毛綱)、Harpcitcoida (ソコミジンコ 目）、Ostracoda (カイムシ下綱) は門、綱、目亡分類の階層がまちまちです。 Meiobenthos の分類は非常に難解なようですが、統一された方が良いようにも思 います。これに関して Introduction 中で meiobenthodに関する良い詳細な説明 があった方が良いと思います

—ご指摘の通り、網 (class) レベルに統一しました。節足動物門の分類体系は Joe i らの分類に従い(26)、Harpacticoida (目) は Maxillopoda (網)へ、 Tana idacea は Mal acostraca（網)へと表記を訂正しました。Ostracoda は Joei らの分類では網であるため、そのまま表記しました。Nematodaに関しましては 網レベルの分類が非常に困難であるため、例外として門レベルで書きその旨を 138 行目に書き加えました。訂正した部分は以下の通りです。 また 62-64 行目にメイオベントスの定義、説明及び引用文献を加えました。訂 正した部分は以下の通りです。

L62-64:Meiobenthos are defined as animal that pass through a 1-mm mesh filter and are known to be composed of a variety of fauna corresponding to 22 phyla [19].

L138-139:Classification of meiobenthos was performed at the level of Class according to Robert et al. [19] except for nematoda due to the difficulty in classification of this species. Classification of arthropods was performed according to Joei et al. [26].

L180:Maxillopoda species from Meguma Pond is $1 \mathrm{~mm}$ long.

L223:but Nematoda species and Maxillopoda species showed no activity.

L411-412:Meguma Pond: Lane 1, sediment; lane 2, Nematoda; lane 3, Oligochaeta; lane 4, Maxillopoda; lane 5, microorganisms.

L218: Malacostraca species in Lake Kuccharo (data not shown);

2. Fig. 3について

決まった温度の影響を定性的に見ていることに非常に疑問を持ちます。 ・4 $4^{\circ} \mathrm{C}$ C $30^{\circ} \mathrm{C}$ での酵素活性を定量化することはできませんか? 
一野付湾については新たに $4^{\circ} \mathrm{C}$ に $30^{\circ} \mathrm{Cで}$ 定量的に活性を測定し、その経時的変 化を図 4 として追加致しました。この追加に伴い、測定法について新たに下記 の文章を追加致しました。長節湖については試料が残っていないため前回と同 じく定性的評価のみに留めました。 追加した部分は以下の通りです。

\section{L142-152: Cellulase activity of oligochaeta from Notsuke Gulf was measured} quantitatively according to the modified method of Niiyama and Toyohara [27]. Briefly, two bodies of living oligochaeta were homogenized with cold $110 \mu \mathrm{l}$ phosphate-buffered saline (PBS, containing $140 \mathrm{mM} \mathrm{NaCl}, 2.7 \mathrm{mM} \mathrm{KCl}, 8 \mathrm{mM}$ $\mathrm{Na}_{2} \mathrm{HPO}_{4}$, and $1.5 \mathrm{mM} \mathrm{KH}_{2} \mathrm{PO}_{4}, \mathrm{pH}$ 7.4). Then, $3 \mu \mathrm{l}$ of meiobenthos extract, $3 \mu \mathrm{l}$ of 1 $\mathrm{M}$ sodium acetate buffer ( $\mathrm{pH} 5.9$ ), and $24 \mu \mathrm{l}$ of $1 \% \mathrm{CMC}$ solution were mixed. Reactions were carried out at $30^{\circ} \mathrm{C}$ and $4^{\circ} \mathrm{C}$ for $1,3,7,12$, and $24 \mathrm{~h}$ with shaking. After incubation, the mixtures were heated at $100^{\circ} \mathrm{C}$ for $3 \mathrm{~min}$ in the block incubator described above to terminate the enzyme reaction. The amount of reducing sugar produced was measured by the tetrazolium blue method [25]. The absorbance at $660 \mathrm{~nm}$ was measured with a UV-mini 1240 spectrophotometer.

L251-252: Figure 4 shows the cellulase activity of oligochaeta species in Notsuke Gulf. Higher activity was detected at $30^{\circ} \mathrm{C}$ than at $4^{\circ} \mathrm{C}$. It should be stressed that the activity level at $4^{\circ} \mathrm{C}$ was almost corresponded with $30 \%$ of that at $30^{\circ} \mathrm{C}$.

L291-295: As shown in Fig.3, Oligochaeta species demonstrated the substantial cellulase activity at $4^{\circ} \mathrm{C}$ in qualitative analysis. Oligochaeta species in Notsuke Gulf actually demonstrated the activity at $4{ }^{\circ} \mathrm{C}$ almost corresponded with $30 \%$ of that at $30^{\circ} \mathrm{C}$ (Fig.4), suggesting that meiobenthos might play any role to degrade plant residues at low temperature.

L425-426: Figure 4 Cellulase activity of oligochaeta species in Notsuke Gulf at $4^{\circ} \mathrm{C}$ and $37^{\circ} \mathrm{C}$ as a function of time. Values are mean \pm standard deviation $(n=3)$.

・また line266にあるように0/ igochaeta が $4{ }^{\circ}$ Cのセルロース分解において重要

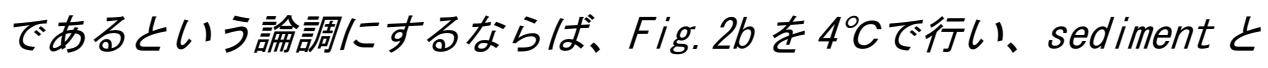
microorganism のバンドも同時に考察すべきです。

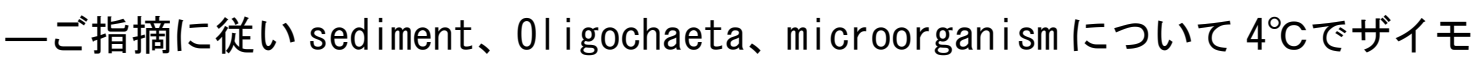
グラフィーを行い、その結果をFig. 3a として元のものと差し替えました。 


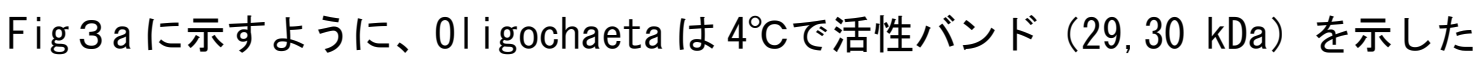
ことから、低温度においてもセルロース分解を有しており、底泥中のセルロー ス分解になんらかの役割を果たしていることが推測されます。しかし、底泥自 体のセルロース分解バンド $(172,146$ kDa ) と0I igochaeta のバンドのサイズは 一致しないことから、野付湾底泥において 01 igochaeta のセルラーゼは主役で はないと考えられます。したがって旧原稿で 267 行目に記述しました「重要な」 という表現は正確ではないので、新たな原稿では下記のように訂正いたしまし た。

L294-295:, suggesting that meiobenthos might play any role to degrade plant residues at low temperature.

L273-279:SDS-PAGE zymographic analysis revealed that the molecular size of active cellulase bands in sediments from Notsuke Gulf (peat fen) corresponded with those from culture medium of microorganisms. To confirm microorganism cellulases actually act at cold temperature, we measured activity at $4^{\circ} \mathrm{C}$. As shown in Fig. 3(a), culture medium of microorganisms showed active bands of 146 and $172 \mathrm{kDa}$, suggesting that microorganism cellulases might play any function in cellulose breakdown in Notsuke Gulf.

3. Sediment とセルラーゼの関係について

・審査員 1 も指摘しているように sediment 中のセルラーゼと meiobenthos、 microorganism のセルラーゼの関係が今一つ不鮮明です。meiobenthos、 microorganismから分泌されたセルラーゼが sediment 中の因子に結合している という記述（出来れば引用文献）があった方がよいと思います。

一最近私どもの研究室から菌のセルラーゼが底泥成分、特に植物残椬に強く吸 着するということを示す論文を発表いたしました（参考文献 31）。また予備実 験ではありますが、ヤマトシジミのセルラーゼが同様に植物残椬等の底泥成分 に吸着性を示す結果も得ております。これらの内容を踏まえ新たに、行目に「北 海道の泥炭湿地において、微生物由来のセルラーゼが底泥成分に吸着して活性 を発現している可能性があること、及びメイオベントス由来のセルラーゼも同 様に北海道湿地帯において底泥成分に吸着した形で活性を発現している可能性 があること」を示す文章を追加致しました。新たに挿入した部分は以下の通り です。 
L303-309:(iv) Liu and Toyohara reported that fungal cellulase actually bound to plant residues [31], it seems likely that cellulases secreted from microorganisms would bind to plant residues and degrade them in the wetlands of peat fen sediments. . In our preliminary experiments, cellulases from Corbicula japonica bound to plant residues similar to fungal cellulases (data not shown), meiobenthos cellulases would function as sediment-binding form in sediment of Hokkaido wetlands.

Minor points

Line 25

--Lake Utonai (lagoon) was potentially due to fungal cellulose

$\rightarrow$ Lake Utonai (lagoon) was potentially due to microorganism cellulose 一ご指摘に従い訂正いたしました。訂正した箇所は以下の通りです。

L25-26: Lake Utonai (lagoon) was potentially due to microorganism cellulose

\section{Line 59}

Recent/y, we showed

$\rightarrow$ Recent $/ y$, it was shown（文献 18 に本論文著者の名前なし）

一ご指摘に従い訂正いたしました。訂正した箇所は以下の通りです

L59-62: Recently, it was shown that the cellulase activities in these northern areas of Japan can be ascribed to meiobenthos, but not to microorganisms, and suggested that meiobenthos play an important role in the breakdown of cellulose, especially in cold climates [18]. 
和文要旨

成因が異なる北海道の湿地帯底泥におけるセルロース分解に果たすメイオベン

トスと微生物の役割

山田京平，豊原治彦（京大院農）

寒冷地湿地帯のセルロース分解機構を明らかにする目的で，北海道の湿地帯 17 か所の底泥のセルロース分解活性を測定した。その結果，泥炭湿地が特に活性 が高く，海跡湖，河口域の順に活性は低下した。活性の定性分析の結果，メグ マ沼（泥炭湿地），野付湾（泥炭湿地）及びウトナイ湖（海跡湖）では微生物が, 長節湖（海跡湖）ではメイオベントスが分解に関わっていることが示された。 以上の結果から，寒冷地湿地帯底泥のセルロース分解には微生物がやメイオベ ントス由来のセルラーゼが重要な働きを果たしていることが示唆された。

キーワード : 寒冷地, 菌類, 湿地帯, セルロース, セルラーゼ, 底泥, 北海道, メイオベントス 
Fig.1

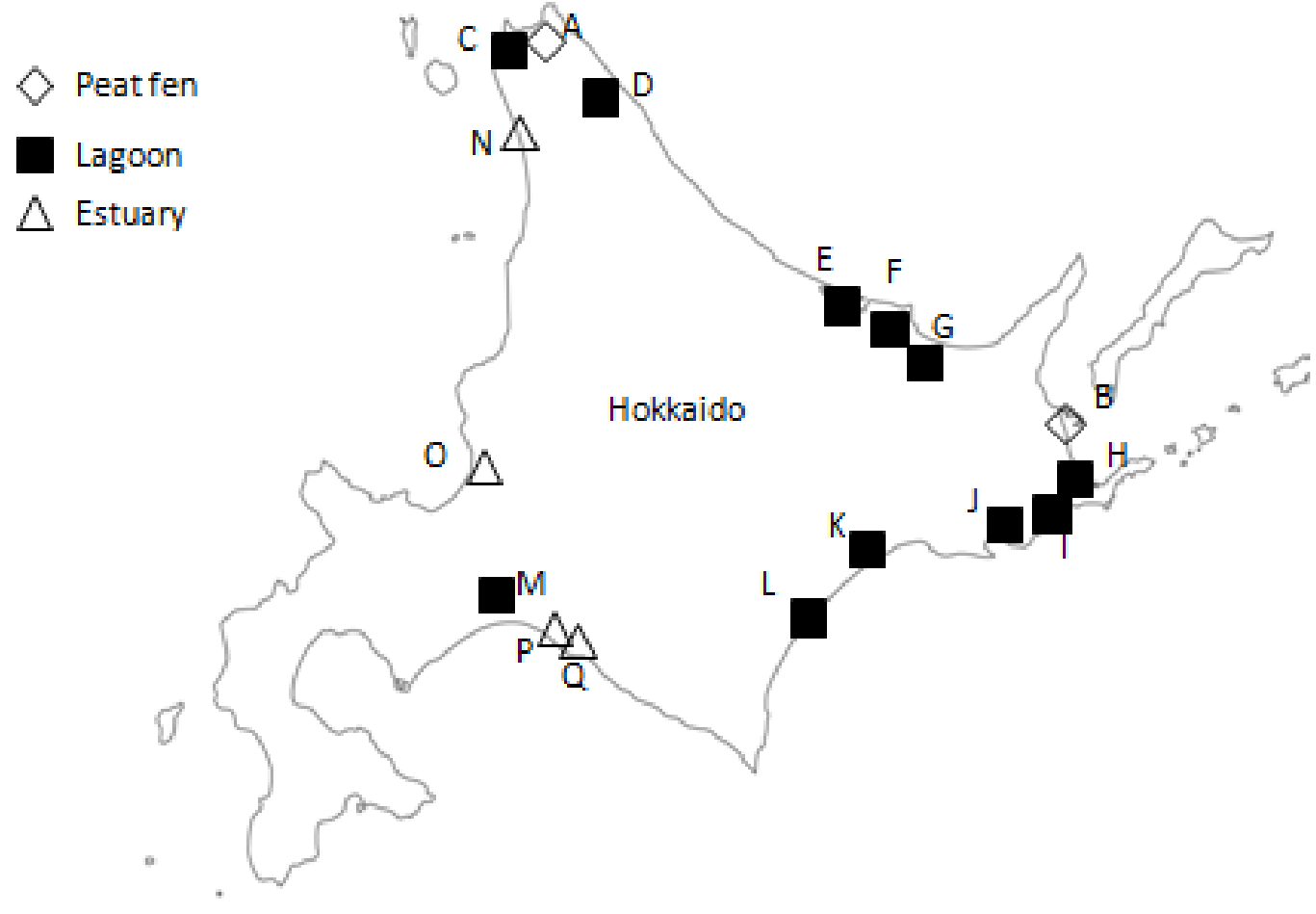


Fig.2
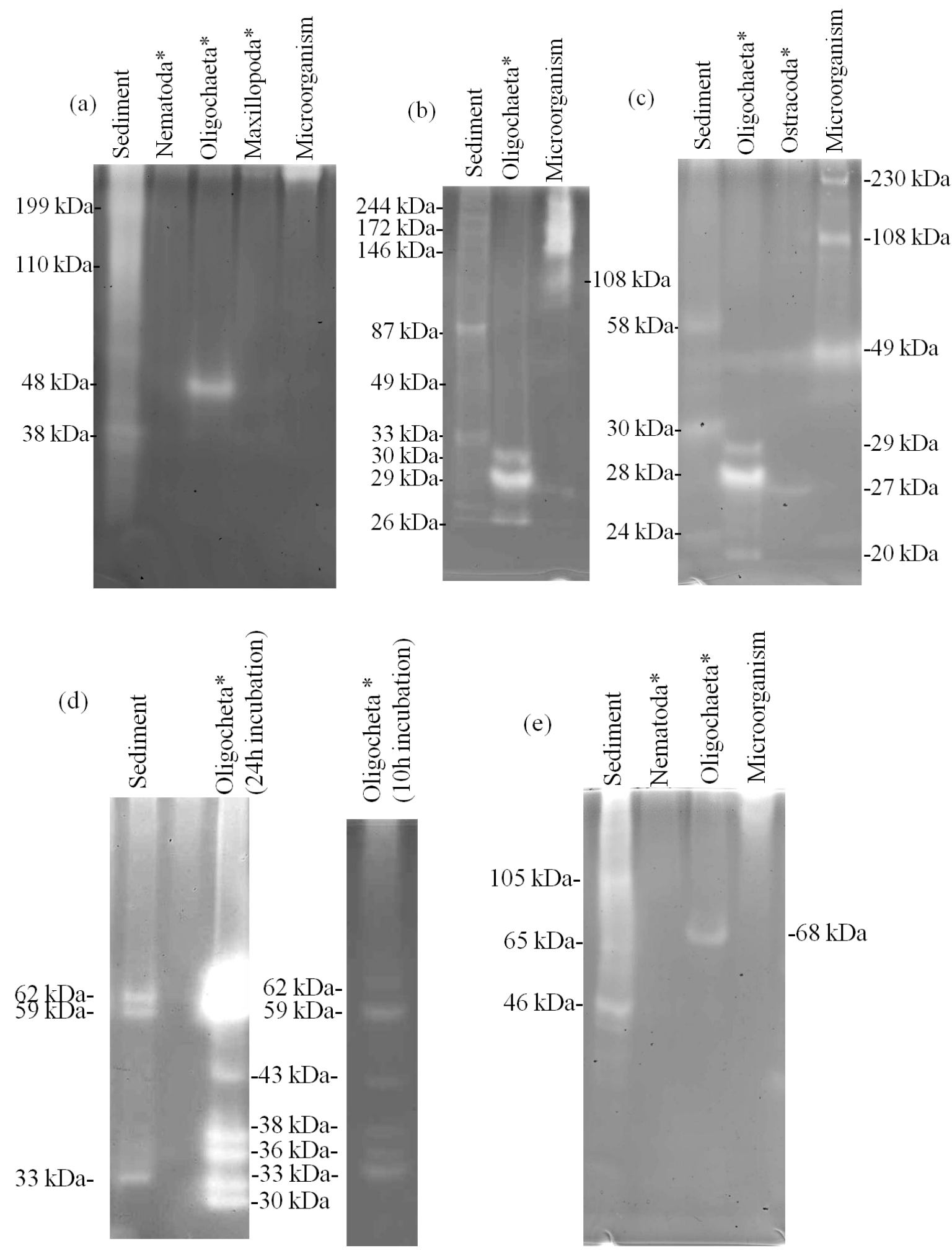
Fig.3

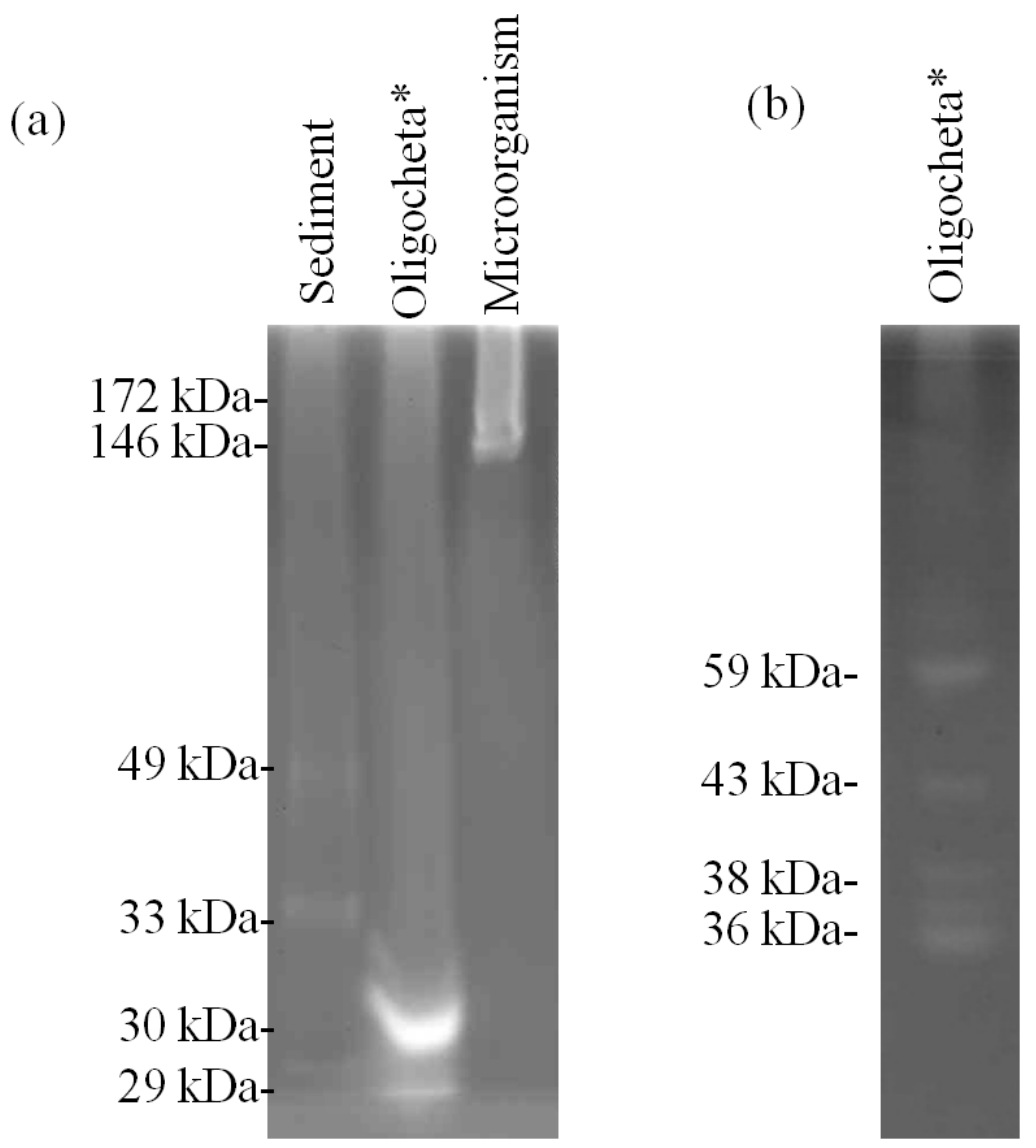


Fig.4

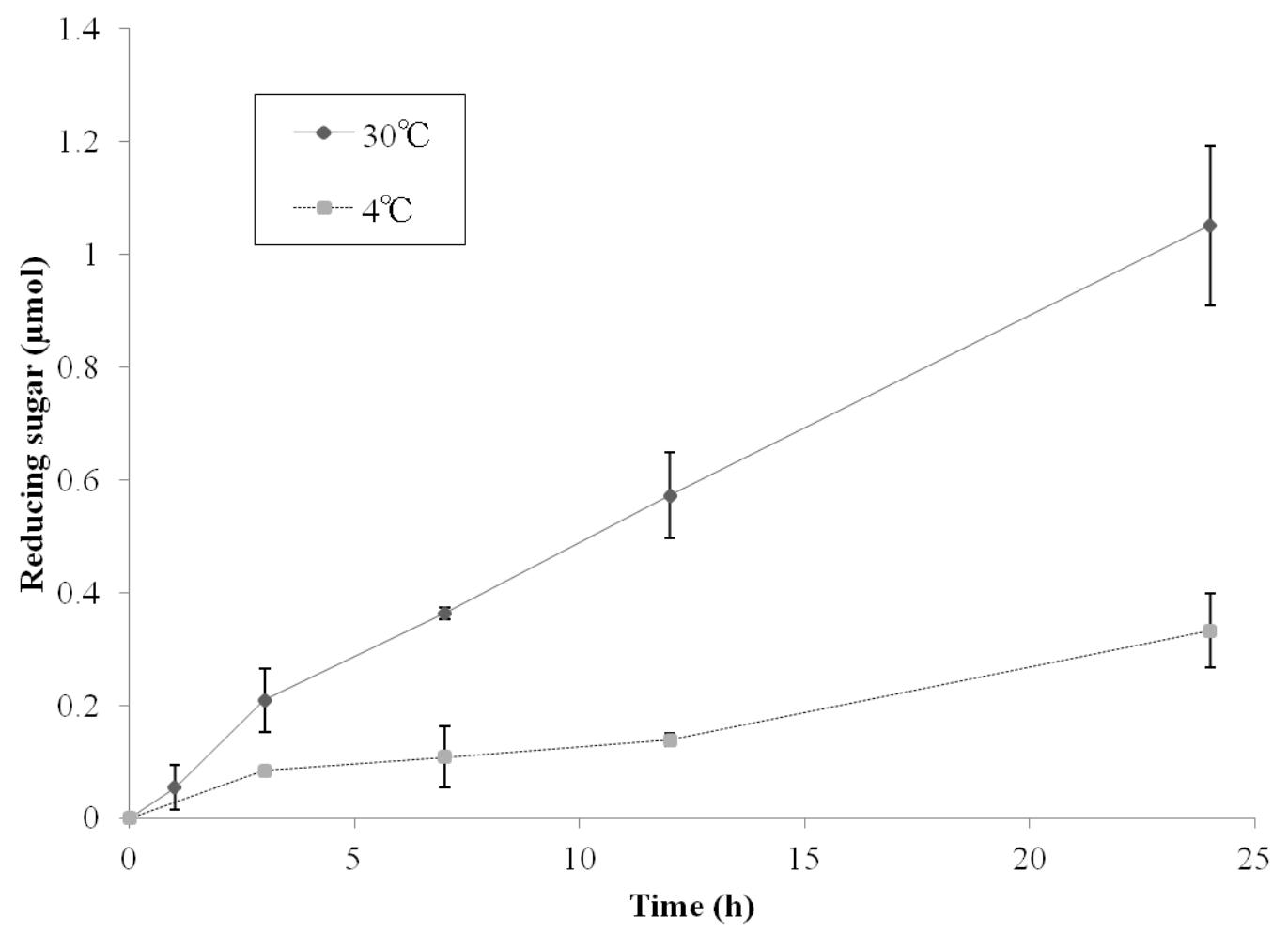


Table 1 Comparison of cellulose activities among wetlands in Hokkaido. Cellulase

activity was determined by the quantitative assay as described in the text

\begin{tabular}{|c|c|c|c|c|c|c|}
\hline Site & Wetland & Location & $\begin{array}{l}\text { Geological } \\
\text { type }\end{array}$ & $\begin{array}{l}\text { Cellulase activity } \\
(\mathrm{nmol} / \mathrm{gh})^{\mathrm{a}}\end{array}$ & $\begin{array}{c}\text { Organic } \\
\text { component } \\
\text { ratio }(\%)^{\mathrm{a}}\end{array}$ & $\begin{array}{c}\text { Salinity } \\
(\%)\end{array}$ \\
\hline A & Meguma Pond & $\begin{array}{l}45^{\circ} 24^{\prime} \mathrm{N} \\
141^{\prime} 49 \mathrm{E}\end{array}$ & peat fen & $737.88 \pm 35.69$ & 66.62 & 0 \\
\hline B & Notsuke Gulf & $\begin{array}{l}43^{\circ} 61^{\prime} \mathrm{N} \\
145^{\circ} 27^{\prime} \mathrm{E}\end{array}$ & peat fen & $92.39 \pm 0.79$ & 16.85 & 26 \\
\hline $\mathrm{C}$ & Onuma Pond & $\begin{array}{l}45^{\circ} 23^{\prime} \mathrm{N} \\
141^{\circ} 46^{\prime} \mathrm{E}\end{array}$ & lagoon & $6.74 \pm 1.28$ & 0.96 & 9 \\
\hline $\mathrm{D}$ & Lake Kuccharo & $\begin{array}{l}45^{\circ} 13^{\prime} \mathrm{N} \\
142^{\circ} 25^{\prime} \mathrm{E}\end{array}$ & lagoon & $6.31 \pm 0.29$ & 1.07 & 14 \\
\hline $\mathrm{E}$ & Lake Saroma & $\begin{array}{l}44^{\circ} 08^{\prime} \mathrm{N} \\
143^{\circ} 57^{\prime} \mathrm{E}\end{array}$ & lagoon & $28.48 \pm 0.66$ & 1.48 & 25 \\
\hline $\mathrm{F}$ & Lake Notoro & $\begin{array}{l}44^{\circ} 06^{\prime} \mathrm{N} \\
144^{\circ} 10^{\prime} \mathrm{E}\end{array}$ & lagoon & $13.86 \pm 0.81$ & 1.84 & 23 \\
\hline G & Lake Abashiri & $\begin{array}{l}43^{\circ} 59^{\prime} \mathrm{N} \\
144^{\circ} 13^{\prime} \mathrm{E}\end{array}$ & lagoon & $2.80 \pm 0.26$ & 0.78 & 0 \\
\hline $\mathrm{H}$ & Lake Furen & $\begin{array}{l}43^{\circ} 18^{\prime} \mathrm{N} \\
145^{\circ} 19^{\prime} \mathrm{E}\end{array}$ & lagoon & $4.22 \pm 0.69$ & 16.68 & 17 \\
\hline I & Mochirippu Pond & $\begin{array}{l}43^{\circ} 01^{\prime} \mathrm{N} \\
145^{\circ} 01^{\prime} \mathrm{E}\end{array}$ & lagoon & $4.31 \pm 0.35$ & 6.65 & 26 \\
\hline $\mathrm{J}$ & Lake Akkeshi & $\begin{array}{l}43^{\circ} 03^{\prime} \mathrm{N} \\
144^{\circ} 51^{\prime} \mathrm{E}\end{array}$ & lagoon & $21.42 \pm 1.11$ & 6.45 & 20 \\
\hline K & Pashikuru Pond & $\begin{array}{l}42^{\circ} 92^{\prime} \mathrm{N} \\
144^{\circ} 00^{\prime} \mathrm{E}\end{array}$ & lagoon & $6.65 \pm 1.32$ & 0.65 & 0 \\
\hline $\mathrm{L}$ & Lake Chobushi & $\begin{array}{l}42^{\circ} 65^{\prime} \mathrm{N} \\
143^{\circ} 61^{\prime} \mathrm{E}\end{array}$ & lagoon & $1.58 \pm 0.23$ & 1.69 & 3 \\
\hline M & Lake Utonai & $\begin{array}{l}42^{\circ} 70^{\prime} \mathrm{N} \\
141^{\circ} 70^{\prime} \mathrm{E}\end{array}$ & lagoon & $44.45 \pm 2.00$ & 1.49 & 0 \\
\hline $\mathrm{N}$ & Teshio River & $\begin{array}{l}44^{\circ} 54^{\prime} \mathrm{N} \\
141^{\circ} 43^{\prime} \mathrm{E}\end{array}$ & estuary & $5.88 \pm 0.50$ & 1.04 & 0 \\
\hline
\end{tabular}




\begin{tabular}{|c|c|c|c|c|c|c|}
\hline $\mathrm{O}$ & Ishikari River & $\begin{array}{l}43^{\circ} 15^{\prime} \mathrm{N} \\
141^{\circ} 22^{\prime} \mathrm{E}\end{array}$ & estuary & $2.58 \pm 0.58$ & 1.23 & 2 \\
\hline $\mathrm{P}$ & Mukawa River & $\begin{array}{l}42^{\circ} 33^{\prime} \mathrm{N} \\
141^{\circ} 55^{\prime} \mathrm{E}\end{array}$ & estuary & 0 & 1.41 & 0 \\
\hline Q & Saru River & $\begin{array}{l}42^{\circ} 30^{\prime} \mathrm{N} \\
142^{\circ} 00^{\prime} \mathrm{E}\end{array}$ & estuary & 0 & 1.48 & 0 \\
\hline
\end{tabular}

${ }^{a}$ Cellulase activity and organic component ratio showed a strong positive correlation $(r$ $=0.96) . p$ value was calculated as $8.78 \times 10^{-10}$, which was statistically significant $(P<0.01)$. Thus, null hypothesis that the coefficient is zero is completely excluded. 
Table 2 Composition of grain size of 17 wetlands in Hokkaido

\begin{tabular}{|c|c|c|c|c|c|c|}
\hline \multirow[b]{2}{*}{ Site } & \multirow[b]{2}{*}{ Wetland } & \multicolumn{5}{|c|}{ Composition by weight of grain size (\%) } \\
\hline & & $>1 \mathrm{~mm}$ & $\begin{array}{l}1 \mathrm{~mm}- \\
500 \mu \mathrm{m}\end{array}$ & $\begin{array}{l}500 \mu \mathrm{m}- \\
250 \mu \mathrm{m}\end{array}$ & $\begin{array}{l}250 \mu \mathrm{m}- \\
63 \mu \mathrm{m}\end{array}$ & $63 \mu \mathrm{m}>$ \\
\hline A & Meguma Pond & $\mathrm{ND}^{\mathrm{a}}$ & $\mathrm{ND}^{\mathrm{a}}$ & $\mathrm{ND}^{\mathrm{a}}$ & $\mathrm{ND}^{\mathrm{a}}$ & $\mathrm{ND}^{\mathrm{a}}$ \\
\hline B & Notsuke Gulf & 14.34 & 11.12 & 40.38 & 9.58 & 24.58 \\
\hline $\mathrm{C}$ & Onuma Pond & 46.36 & 19.40 & 25.54 & 7.16 & 1.54 \\
\hline $\mathrm{D}$ & Lake Kuccharo & 40.30 & 10.34 & 25.54 & 21.98 & 1.84 \\
\hline E & Lake Saroma & 26.90 & 57.60 & 12.58 & 1.50 & 1.42 \\
\hline $\mathrm{F}$ & Lake Notoro & 6.96 & 39.60 & 37.18 & 15.42 & 0.84 \\
\hline G & Lake Abashiri & 18.15 & 47.76 & 26.71 & 7.38 & 0 \\
\hline $\mathrm{H}$ & Lake Furen & 40.94 & 23.96 & 24.98 & 8.66 & 1.46 \\
\hline I & Mochirippu Pond & 15.58 & 36.64 & 36.96 & 10.24 & 0.58 \\
\hline $\mathrm{J}$ & Lake Akkeshi & 18.80 & 28.26 & 22.24 & 25.40 & 5.30 \\
\hline K & Pashikuru Pond & 11.38 & 10.10 & 39.28 & 38.76 & 0.48 \\
\hline $\mathrm{L}$ & Lake Chobushi & 76.50 & 13.60 & 7.15 & 2.75 & 0 \\
\hline M & Lake Utonai & 58.40 & 28.64 & 8.39 & 4.56 & 0 \\
\hline $\mathrm{N}$ & Teshio River & 9.44 & 35.61 & 48.17 & 6.78 & 0 \\
\hline $\mathrm{O}$ & Ishikari River & 0 & 2.35 & 88.06 & 9.59 & 0 \\
\hline $\mathrm{P}$ & Mukawa River & 25.40 & 48.74 & 12.06 & 13.38 & 0.42 \\
\hline Q & Saru River & 2.08 & 10.90 & 64.92 & 21.46 & 0.64 \\
\hline
\end{tabular}

${ }^{a}$ ND: not determined 